\title{
Marine colonization and biodiversity at Ascension Island and remote islands
}

\author{
DAVID K.A. BARNES \\ British Antarctic Survey, Natural Environment Research Council, High Cross, Madingley Road, Cambridge CB3 OET, UK
}

\begin{abstract}
Little is known about colonization of remote island coasts by marine invertebrates, other than corals. The structure of hard substrata assemblages was investigated across Ascension Island's littoral zone in comparison with other sites. Arrays of acrylic panels were deployed at two sites for 2 years at Ascension Island to measure subtidal recruitment. Colonization of panels at Ascension I. was low, though space occupation, abundance and richness varied considerably. After $\sim 1$ and 2 years Ascension panels were $<17$ and $<37 \%$ covered by fauna and each had $<22$ recruits and 54 recruits (per $100 \mathrm{~cm}^{2}$ ) respectively, amongst the lowest density of recruits reported. Recruitment rates of corals $\left(25 \mathrm{~m}^{2}\right.$ year $\left.{ }^{-1}\right)$ at Ascension I. were also similar to the lowest levels reported elsewhere (e.g. at Bermuda or Midway islands). Less dispersive animal types, e.g. cheilostome bryozoans, were poorly represented. Panels immersed in Tanzania and Scotland were $>30 \%$ covered, with $>76$ recruits per $100 \mathrm{~cm}^{2}$ and with bryozoans well represented after 1 year. Across-littoral surveys of established macrofauna at five remote islands (Ascension I., Easter I., Azores, South Georgia and Signy I., Antarctica) revealed similar trends of a rich sublittoral and lower littoral reducing drastically up-shore; molluscs dominating abundance and species numbers, whilst polychaetes, crustaceans and echinoderms were well represented. Established sessile animals occurred patchily at a mean density of $8.26 \mathrm{~m}^{-2}$ but recruits had mortality levels $>99 \%$. Polar or remote temperate/tropical sites are typically less colonized than at nonremote, low latitudes but the lowest levels reported are at remote polar sites. Reduced colonization at Ascension island reflects remoteness.
\end{abstract}

Keywords: recruitment, isolation, dispersal, coral, latitude

Submitted 5 June 2015; accepted 21 August 2015; first published online 28 September 2015

\section{INTRDDUCTION}

Increasing isolation and decreasing size and age of islands all represent increasing challenges for coastal organisms to reach and establish on their shores. Ascension Island is a small, young (less than 1.5 million years old, see Mitchell-Thome, 1982) mid-ocean island $1500 \mathrm{~km}$ from the nearest (W African) continent margin. The native megafauna on this remote volcanic rock is famously dominated by geograpsid land crabs, seabirds and green turtle migrants. The littoral and sublittoral fauna have been little studied and its shores appear quite barren (partly attributed to trigger fish grazing, see Price \& John, 1978, 1980), though it is known to include many endemics. Numerous coastal amphipods, more than $15 \%$ of its shore fish, two shrimps (Procaris ascensionis Chace \& Manning 1972 and Typhlatya rogersi Chace \& Manning, 1972) and other invertebrates have been found nowhere else (Lubbock, 1980; Biernbaum, 1996). Remote Atlantic islands have been important for studies of terrestrial organism colonization and dispersal, but such places also represent equally good opportunities to examine marine colonization. Holmes et al. (1997) used artificial substrata (settlement panels) in the west Pacific to show that sublittoral colonization was lower on offshore than nearshore islands, mainly due to the rarity of taxa with non-planktotrophic

Corresponding author:

D.K.A. Barnes

Email: dkab@bas.ac.uk larvae, such as most cheilostomatid bryozoans. However, cheilostomatid bryozoans were major colonizers of panels deployed at old, remote islands, such as Signy I., Antarctica and arctic Spitsbergen (Stanwell-Smith \& Barnes, 1997; Barnes \& Kuklinski, 2005). These authors were unclear though, whether the low colonization was attributable to their locations being polar or isolated. Ascension I. is an ideal study site for investigation of how dispersal opportunities of a taxon influences representation at 'hard targets' such as remote, young islands. Examining levels of colonization at Ascension I. should aid interpretation of results from colonization studies of isolated localities elsewhere.

When Barnes (1996) and Stanwell-Smith \& Barnes (1997) reported very low overall levels of space occupation on settlement panels immersed at Signy I. Antarctica, they suggested that polar colonization rates were very low. A new study of recruitment to immersed coastal panels in arctic Spitsbergen also found very little fauna compared with typically reported levels of richness, space occupation or abundance (Barnes \& Kuklinski, 2005). Although old, the islands of Signy and Spitsbergen are both situated in mid-ocean archipelagos, so remoteness is also a potential explanation for reduced metrics of colonization compared with elsewhere. Recent studies of recruitment to subtidal settlement panels around the continent margin of Antarctica have revealed much higher levels of colonization, as well as high between-site variability (Bowden et al., 2006; Stark unpublished data). Both Bowden et al. and Stark's studies showed levels of colonization after 2-3 years that fall within the variability reported from equivalent temperate and tropical experiments (Winston \& Jackson, 1984; Todd, 1998; 
Maughan, 2000). Holmes et al. (1997) found the effect of isolation was much greater than latitude in the colonization of subtidal panels along the east Australian coast and similarly Davenport \& Stevenson (1998) found impoverished littoral colonization at remote South Georgia compared with nearshore Cumbrae I. In contrast Schoener et al. (1978) found colonization of panels submerged at isolated Hawaii to be similar to patterns in Thailand. Comparisons are difficult as there are so few data reported from remote localities, with the possible exception of coral recruitment. Surveys of faunistic richness or diversity of adult communities have been reported for some remote island coasts (e.g. Węsławski et al., 1988; Beckley \& Branch, 1992; Cole et al., 1992; Bourmaud et al., 2005) but more typically such studies are restricted to one zone or group of animals (e.g. Moyano, 1973; Pugh \& Mercer, 2001; Bouchet et al., 2002). Coral recruitment has been the major focus of investigations into marine colonization of remote islands, such as at Hawai and Bermuda (see Fitzhardinge, 1985; Smith, 1985, 1992; Friedlander et al., 2005). Few studies have ever reported rates across marine fauna for a remote tropical (or temperate) island.

In the current study the biodiversity of isolated localities (focusing on Ascension I.) was investigated using artificial substrata and surveys from the subtidal to the supralittoral. Acrylic settlement panels were deployed in the shallow subtidal for 2 years at Ascension I. and, for comparison, at two continent margin sites - a matched tropical latitude in Tanzania and a temperate site in west Scotland (UK). Surveys of sublittoral, littoral and supralittoral macrobenthos were conducted at Ascension I., Easter I., the Azores, and South Georgia and Signy islands in Antarctica. The aim of the current study is to determine the rates and variability of coastal colonization at an isolated young tropical locality and its pattern of richness across the terrestrial-marine interface zone. It is hypothesized that at Ascension I.: (1) colonization to panels will be low and that taxa with non-pelagic larvae will be poorly represented; and (2) trends of richness from sublittoral to supralittoral zones will show similar patterns to elsewhere but with overall depressed levels.

\section{MATERIALS AND METHODS}

Young and established coastal communities at Ascension I. (South Atlantic) were investigated using settlement panels to measure recruitment and transect surveys to quantify established adults. Recruitment was measured at two other nonremote sites and adult communities were assessed at several other remote sites for comparison with Ascension Is. data.

\section{Study apparatus and area}

Artificial substrata in the form of settlement panels $(15 \times$ $15 \times 0.5 \mathrm{~cm}^{3}$ ) were deployed in the shallow subtidal zone at a series of sites. Each panel was cut from black acrylic sheet and machine-sanded (following Turner \& Todd, 1993; Todd \& Keough, 1994; Barnes \& Kuklinski, 2005; Bowden et al., 2006). A central $\left(10 \times 10 \mathrm{~cm}^{2}\right)$ analysis area was marked out by drilling a $0.1 \mathrm{~cm}$ groove. Panels were attached to two Perspex rods in threes using plastic nuts and bolts (of $0.5 \mathrm{~cm}$ diameter). Panels were then washed and conditioned (to develop a biofilm) by immersion in local seawater for a period of 3 days. The approximate location for placement of each panel array was selected at random but within these locations, areas were selected which were most sheltered from wave action to minimize chances of dislodgement or damage. Small stainless steel (316 marine grade) hoops were attached to rock surfaces using two-part aquarium cement and left for 2 days to harden. Each conditioned triplicate array was then attached, using cable ties, to these stainless steel hoops. Arrays were mounted such that each was approximately horizontal and plastic spacers were used to ensure the under-surface of each panel was $\sim 2 \mathrm{~cm}$ above the substratum.

At Ascension I., two sites $(\sim 100 \mathrm{~m}$ apart $)$ were selected for panel deployment at each of two localities $(\sim 5 \mathrm{~km}$ apart $)$, English Bay and North East Bay (see Figure 1). Investigation of established adult communities also encompassed a further locality of Shelly Bay. The main difference between these sites was exposure to wave action and prevailing wind.

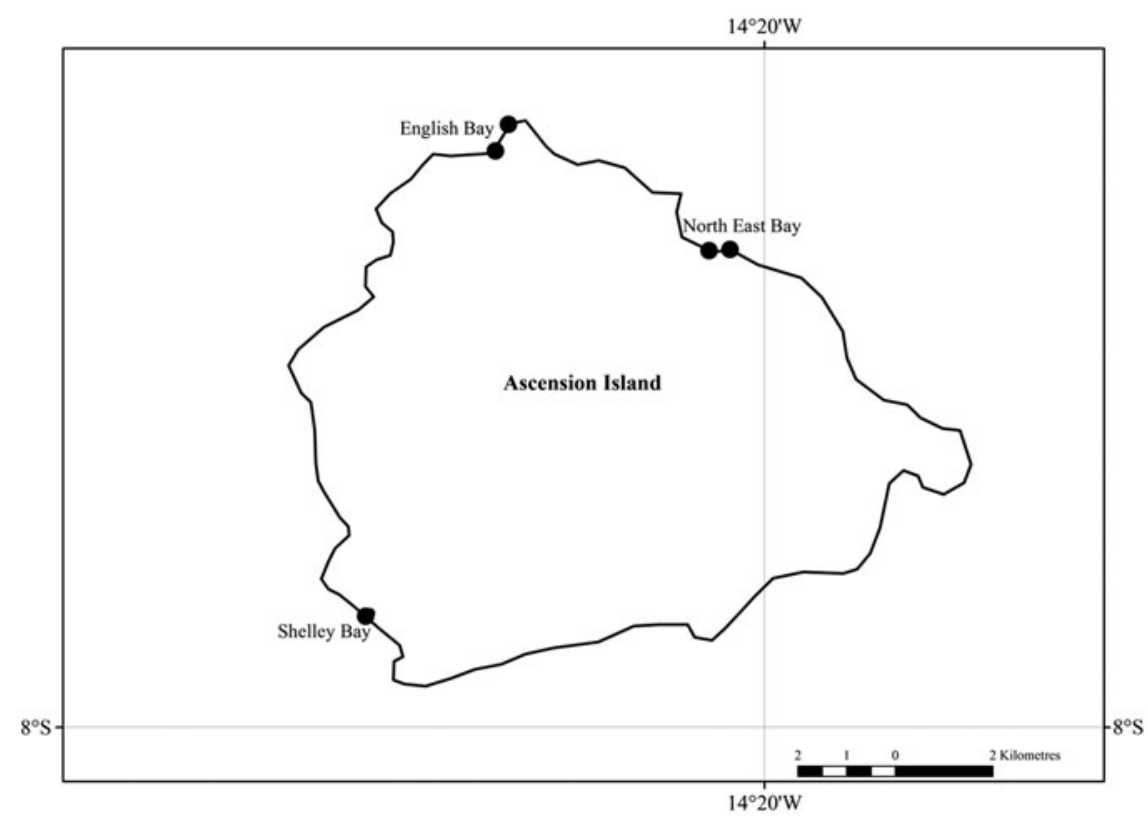

Fig. 1. Position of study sites (filled circles) at Ascension Island, mid Atlantic. 
Shelly Bay was the most exposed to wind and wave and accumulated large amounts of floating volcanic rock (pumice) and other marine debris on the shore. North East Bay was mainly affected by ocean swell and English Bay was the most sheltered, but all three localities would be considered very exposed compared with most European shores (approximate to Ballantine 2-3 sensu Ballantine (1961)). The 24 panels deployed encompassed variability across the scales of $\mathrm{km}$, $100 \mathrm{~m}$, and replicates by this experimental design. Three areas of similar size to panels were scrubbed clean of encrusting biota at each of the two locations. The two bays were characterized by high wave energy, low tidal ranges $\left(\sim_{1.3} \mathrm{~m}\right)$ and volcanic bedrock with few boulders. Little is known of the ecology of coastal marine invertebrates at Ascension I. (but see Irving, 1989) though a number of studies have attempted to describe the species of specific taxa (see Maddocks, 1975; Rosewater, 1975; Markham, 1978; Pawson, 1978; Manning \& Chace, 1990; Biernbaum, 1996; Hoeksema et al., 2017; Zibrowius et al., 2017). During the same study period as the panel deployments at Ascension I., identical panel arrays were also deployed at two localities at each of the following locations; Oban in West Scotland (UK) and the east coast of Pemba I., Tanzania. Comparisons were also made with settlement panel studies using similar apparatus and protocol during the same time period in west Spitsbergen (Svalbard Archipelago, Arctic Norway) (Barnes \& Kuklinski, 2005), Lough Hyne, South West Ireland (Watson \& Barnes, 2004) and Adelaide I., Antarctica (Bowden et al., 2006). The location of the main study areas and important areas of comparison are shown in Figure 2.

\section{Protocol}

Panel arrays were deployed across the years 2002 and 2003. Panels were resurveyed after 1, 3, 11 and 24 months immersion at Ascension I.; 3, 6, 12 and 24 months in W Scotland and 3, 4, 7, 8 and 13 months in Tanzania. A first deployment of panels to the intertidal and shallow subtidal zones at Ascension I. resulted in most panels being lost to storm damage and a series of panels experimentally deployed at $6 \mathrm{~m}$ depth were all carried away by wave action. New deployment using more aquarium cement around the stainless steel hoops and more sheltered microhabitats proved more successful. On retrieval all panels were photographed using a digital camera (Nikon D10o fitted with microNikkor $60 \mathrm{~mm}$ macro lens in an underwater housing) and stored as high-resolution jpg files (with zero compression). Panels were then replaced in the same positions and reattached using new cable ties. Each individual recruit in the central analysis area of each panel was counted (each colony was recorded as one recruit) and identified to the lowest possible taxonomic level using primary literature. The degree of space occupation (\% cover) was evaluated using image analysis, and the number of recruits, genera and classes of animals were counted and recorded per panel. The data were analysed using General Linear Model (GLM) ANOVA in the software package MINITAB 14. The dependent variables were successively percentage cover, generic richness, class richness and density (number of individuals $\mathrm{m}^{-2}$ ). The independent factors at each were spatial (locality and site) and time (duration of immersion). Per cent cover values were arcsine transformed and then all data were checked for normality and homogeneity of variance prior to ANOVA (GLM).

The richness of fauna was investigated along transects at three localities at Ascension Island: English Bay, North East Bay and Shelley Bay. Each transect was sampled at 6 and $3 \mathrm{~m}$ below Extreme Low Water Spring tide level (ELWS), Lower, middle and upper shore and 3 and $6 \mathrm{~m}$ above Extreme High Water Spring tide level (EHWS). On each transect at each of these heights five $1 \times 1 \mathrm{~m}^{2}$ quadrats were randomly deployed, the fauna within them examined and all macroscopic $\left(>_{3} \mathrm{~mm}\right)$ animals identified and counted. A similar protocol was carried out adjacent to the towns of Ponta Delgarda, Sao Miguel I. (Azores Archipelago) in 1998,

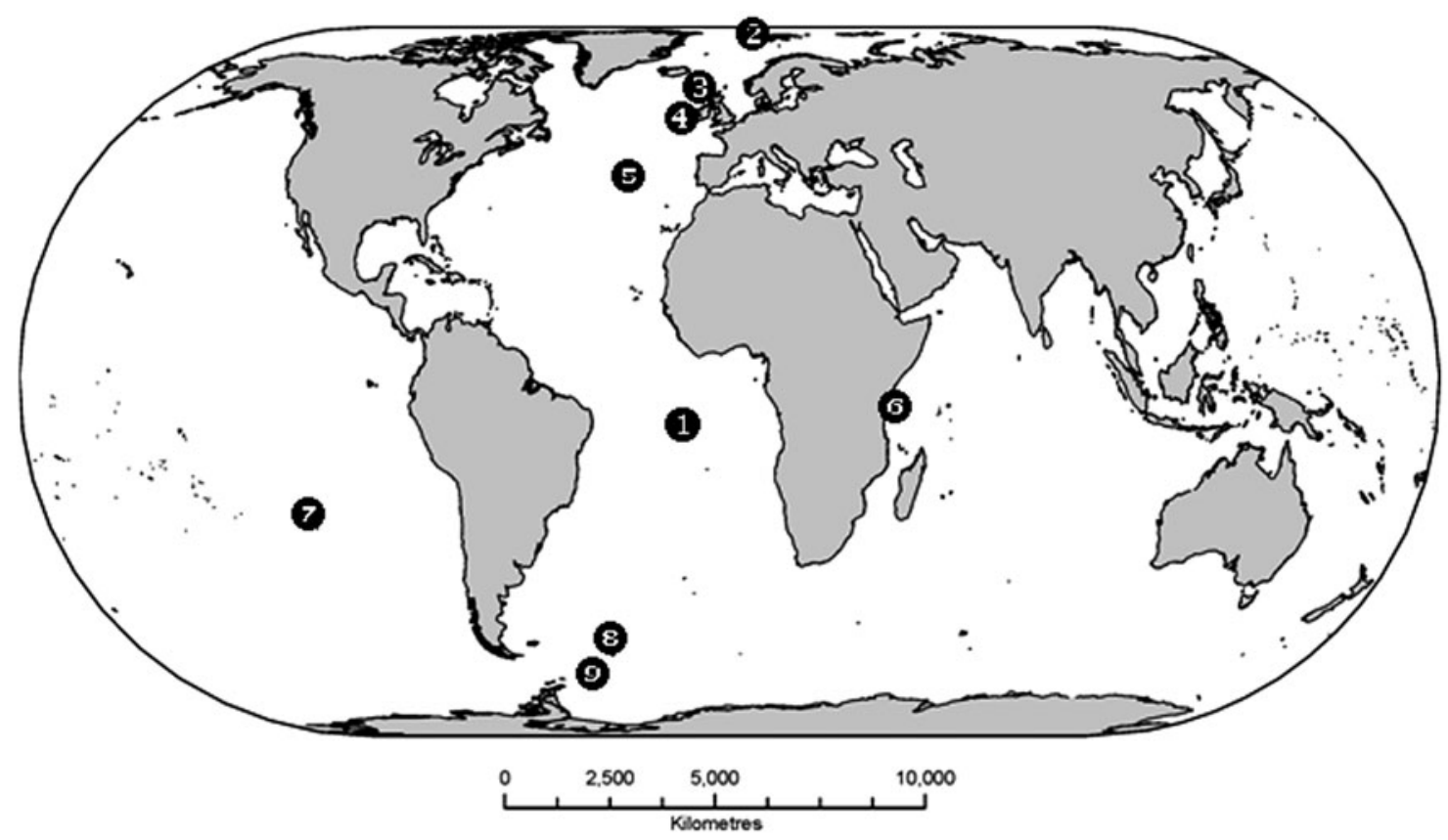

Fig. 2. Sites of coastal colonization and richness studies. The sites are Ascension Island (1), Spitsbergen Island, Arctic (2), W Scotland (3), SW Ireland (4), Miguel Island, Azores (5), Pemba Island, Tanzania (6), Easter Island (7), South Georgia (8) and Signy Island, Antarctica (9). 

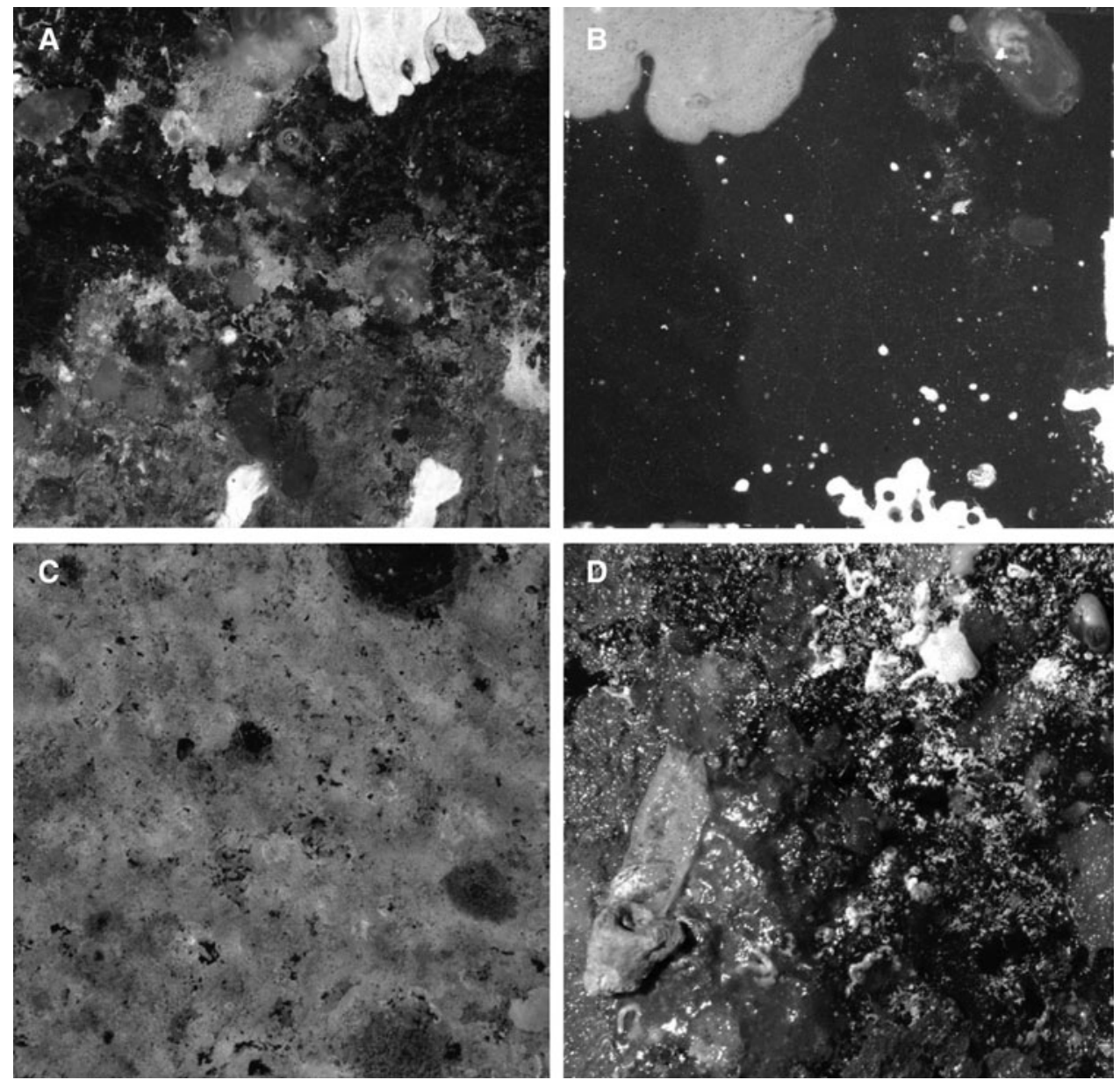

Plate 1. Variability in the level of space occupation and composition of colonizers on settlement panels at Ascension Island. (A and B) are from English Bay, (C) is from North East Bay and D is recolonization of natural rock at North East Bay.

Hanga Roa, Easter I. (Mid Pacific) in 2002 and in Cumberland East Bay, South Georgia in 2005 and Borge Bay, Signy Island (Antarctica) in 1993. Data were displayed as scatter plots of (mean and total) numbers of species with height across the nearshore terrestrial, intertidal and shallow subtidal zones.

\section{RESULTS}

During the course of the study four of the 24 shallow subtidal panel arrays were destroyed at Ascension I. The first settlers on the panels were polychaete (serpulid and spirorbid) worms and solitary ascidians but eventually were also colonized by anthozoan and hydrozoan cnidarians, bivalve molluscs, cheilostome bryozoans and demosponge Porifera. At 11 months the major space occupiers were demosponges and colonial ascidians (Plate 1 ) and after 2 years the panels had developed an encrusting biota that was similar to assemblages on surrounding large boulders. ANOVA identified neither locality nor site as significant factors influencing variability in (genus or class level) richness, abundance or space occupation of assemblages recruiting to the panels at Ascension Island (All ANOVA, $F_{1},{ }_{1}<0.94, P>0.34$ ). The space occupied by encrusting fauna reached a mean of $\sim 36 \%$ by 2 years, though this varied considerably between panels $(12.6-72.4 \%$ - Figure $3 \mathrm{~A})$. Both the numbers of genera and classes of recruits increased rapidly at first but then little from 11 to 24 months, finishing at means of 5.67 and 7.35 for these durations (Figure $3 \mathrm{~B}$ ). Recruit abundance was very low and, especially by the end of year 2, was highly variable with a mean of 54 recruits per panel (per $100 \mathrm{~cm}^{2}$ ) established by the end of the experiment. Coral recruitment was highly variable both on the artificial panels (mean: 0.25 per panel $/ 25$ per $\left.\mathrm{m}^{2}\right)$ and adjacent rock surfaces $\left(0-29 \mathrm{~m}^{2}\right)$ experimentally cleared for comparisons.

The space occupation by encrusting fauna on panels was significantly different across regions (Table 1). Percentage cover at Pemba I., Tanzania and W Scotland were considerably higher than at Ascension I. (Figure 4A). There was little difference in space occupied after the first few months between panels at Ascension I. and other study regions. However, by the time panels had been immersed for about 1 year, fauna, including a diversity of cheilostomatid bryozoans, had covered $35.6 \%( \pm 3.3)$ of panels in Tanzania and $30.0 \%$ $( \pm 2.9)$ of those in W Scotland compared with $<20 \%$ at Ascension I. (Figure 4A). Recruitment to the Tanzanian panels was, at 76.8 per $100 \mathrm{~cm}^{2}$ (mean total) and 0.33 per $100 \mathrm{~cm}^{2}$ (coral), more than double that observed at Ascension I. over a similar period but represents less than half the number recruited to the Scottish panels after 12 months (Figure $4 \mathrm{~B}$ ).

Much of the fauna in the sublittoral, littoral and supralittoral at Ascension I. was cryptic, occurring under boulders or in crevices, resulting in all zones having a denuded appearance. 

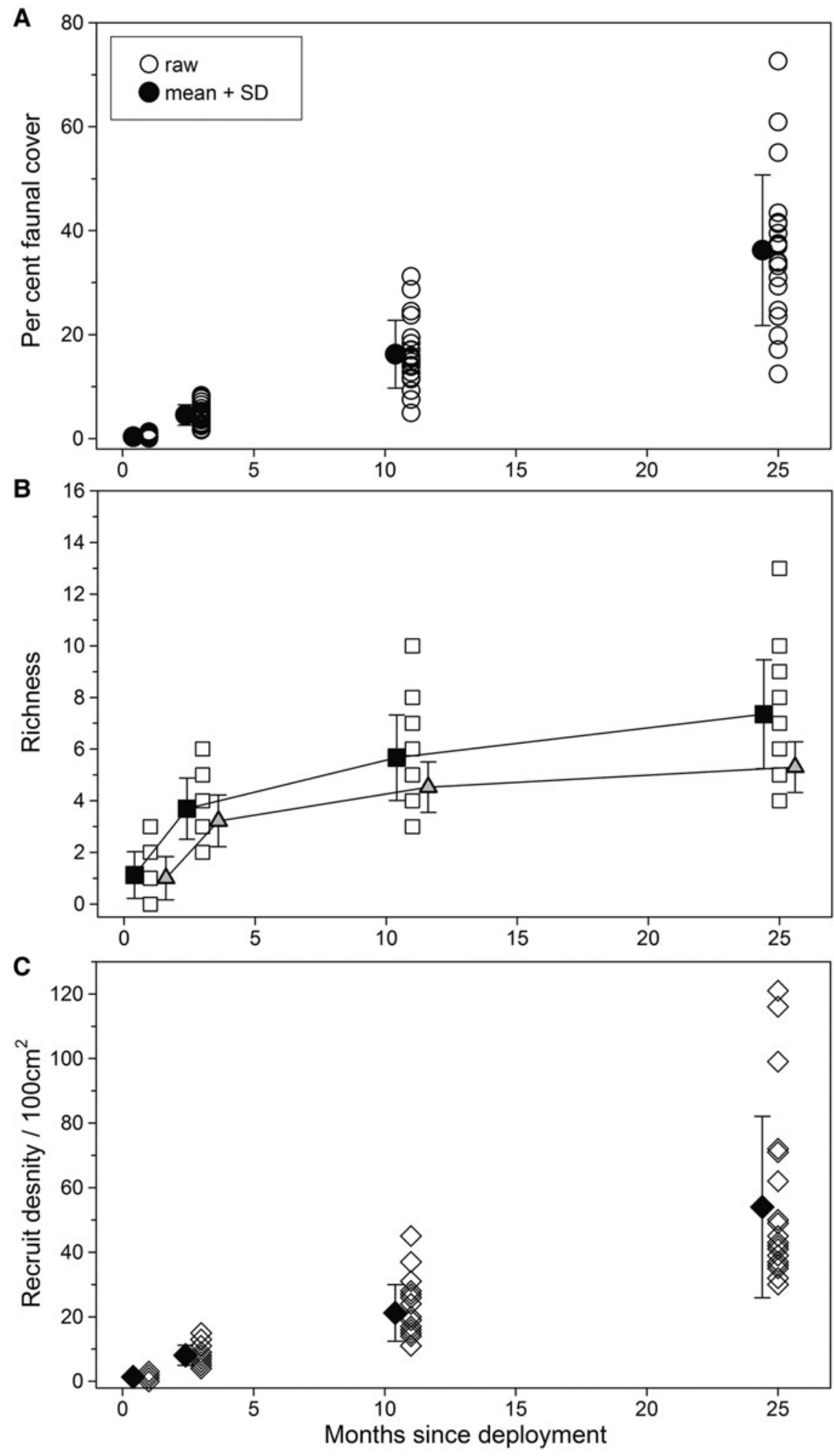

Fig. 3. Space occupation (a), richness (b) and recruit density (c) on shallow subtidal settlement panels at Ascension Island with time. The raw data are offset (on the $\mathrm{x}$ axis) from mean values for clarity.

Molluscs (49.5\%) and polychaete worms (15.8\%) dominated littoral numerical abundance though casual observation suggested echinoderms would dominate the biomass. A total of 35 macrofaunal, principally (endemic) mollusc and crustacean species, were identified along the three Ascension I. subtidalsupralittoral transects (Table 2). The pattern of mean and total species richness was similar across all three Ascension I. study localities (Figure 5), being high in the subtidal and lower shore but drastically declined $(<50 \%$ species $)$ on the mid-shore. Macro-fauna were observed in pools with water temperatures of up to $41^{\circ} \mathrm{C}$, though few macro- or mega-faunal species were obvious above the upper shore, where (colonized) 
Table 1. ANOVA of region (Ascension Island, Tanzania and Scotland) duration of panel immersion and locality.

\begin{tabular}{lrrrrrr}
\hline Source & df & Seq SS & Adj SS & Adj MS & \multicolumn{1}{c}{$\boldsymbol{F}$} & $\boldsymbol{P}$ \\
\hline Region & 2 & 2827.8 & 1355.8 & 677.9 & 12.5 & $<0.001$ \\
Time & 1 & 25354.6 & 25057.8 & 25057.8 & 463.5 & $<0.001$ \\
Locality & 3 & 251.7 & 251.7 & 83.9 & 1.6 & 0.204 \\
Error & 135 & 7298.0 & 7298.0 & & & \\
Total & 141 & 35732.1 & & & & \\
\hline
\end{tabular}

rock temperatures exceeded $56^{\circ} \mathrm{C}$. Transect and quadrat surveys, using the same method and apparatus, of macroand mega-fauna across the littoral zone of other remote islands revealed similar patterns (Figure 6). Richness at subtropical Easter Island and Sao Miguel, Azores both showed increased variability overall and more species (and individuals) in the supralittoral compared with Ascension Island. Across the littoral and supralittoral zones the mean richness of species at the Antarctic localities, Signy Island and South Georgia, were similar to that at Ascension I. (though the variability differed considerably).

Adult sessile fauna formed $69 \pm 3.2 \%$ of established individuals and $55.9 \pm 3.2 \%$ of species recorded in the shallow subtidal of Ascension I. The high level of standard deviation associated with density, $8.26 \pm 7.3 \mathrm{~m}^{2}$, indicates pronounced patchiness associated with a high $\left(5400-8.26\right.$ adults $\mathrm{m}^{2}=$ 99.84\%) post-settlement mortality. Brief observations revealed that this mortality was associated with wave action moving boulders and transient fishes.

\section{DISCUSSION}

Colonization of the Ascension Island coast by marine invertebrates was highly variable in scale comprising types of organism which typically recruit to hard substratum elsewhere. The mean rate of colonization of panels deployed in the shallow subtidal was found to be very low (Figure 3), but general levels of recruitment are, however, consistent with the few studies reported from other remote islands (Table 3 ). The richness and patterns in richness of established (adult) communities across the littoral zone were approximately similar to those on the other studied mid-ocean islands across latitude (Figure 6). Comparing the natural density of recruits to established adults on the panels indicates a massive post settlement mortality.
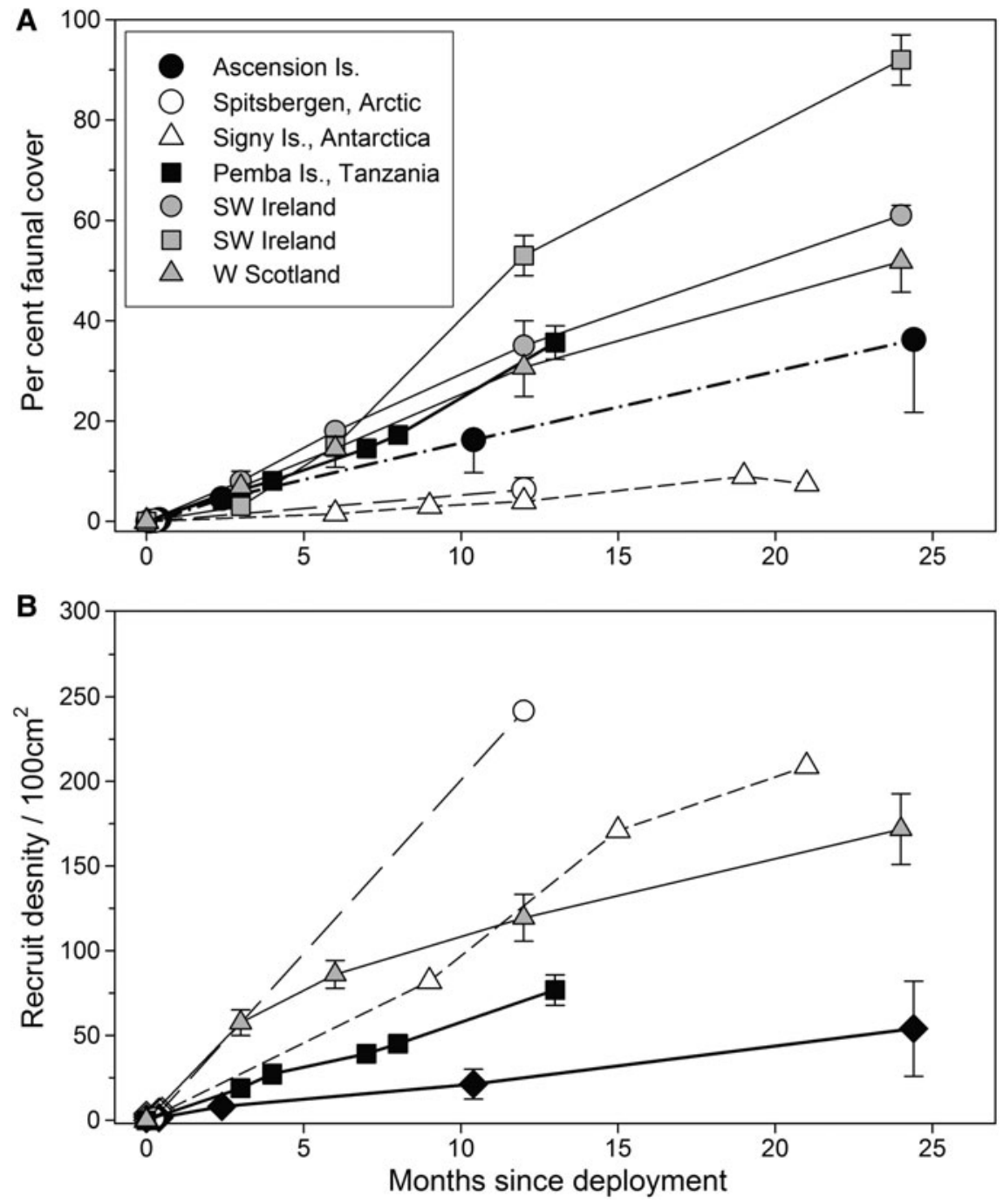

Fig. 4. Mean space occupation (a) and recruit density (b) on shallow subtidal settlement panels with time and location. The key to locations is shown in (A). Data for Spitsbergen are from Barnes \& Kuklinski (2005), for Signy Island from Stanwell-Smith \& Barnes (1997) and for SW Ireland from Maughan (2000). 
Table 2. Macro/megafauna present in study quadrats from $6 \mathrm{~m}$ below Extreme Low Water Spring tide level to $6 \mathrm{~m}$ above Extreme High Water Spring tide level at three sites on Ascension Island.

\begin{tabular}{|c|c|c|c|}
\hline Taxa & $\begin{array}{l}\text { English } \\
\text { Bay }\end{array}$ & $\begin{array}{l}\text { Mars } \\
\text { Bay }\end{array}$ & $\begin{array}{l}\mathrm{NE} \\
\text { Bay }\end{array}$ \\
\hline \multicolumn{4}{|l|}{ Annelida } \\
\hline Eurothoe complanata Pallas 1766 & & & $\checkmark$ \\
\hline Hermodice carunculata Pallas 1766 & $\checkmark$ & & \\
\hline Pileolaria sp. & $\checkmark$ & & $\checkmark$ \\
\hline Serpulidae & $\checkmark$ & & $\checkmark$ \\
\hline \multicolumn{4}{|l|}{ Crustacea } \\
\hline Alpheus macrocheles Hailstone 1835 & & $\checkmark$ & \\
\hline Calcinus tubularis (Linnaeus 1767) & $\checkmark$ & & $\checkmark$ \\
\hline Clibanarius tricolor (Gibbes 1850) & & & $\checkmark$ \\
\hline Cronius rubber (Lamarck 1818) & & & $\checkmark$ \\
\hline $\begin{array}{l}\text { Johngarthia lagostoma (H Milne } \\
\text { Edwards 1837) }\end{array}$ & $\checkmark$ & $\checkmark$ & $\checkmark$ \\
\hline Grapsus adscensionis (Osbeck 1765) & $\checkmark$ & $\checkmark$ & $\checkmark$ \\
\hline $\begin{array}{l}\text { Paractaea rufopunctata (H Milne } \\
\text { Edwards 1834) }\end{array}$ & & $\checkmark$ & \\
\hline Unknown amphipod & $\checkmark$ & & \\
\hline \multicolumn{4}{|l|}{ Echinodermata } \\
\hline Diadema antillarum Philippi 1845 & $\checkmark$ & $\checkmark$ & \\
\hline Echinometra lucunter (Linnaeus 1758) & $\checkmark$ & $\checkmark$ & $\checkmark$ \\
\hline Eucidaris clavata Mortensen 1928 & $\checkmark$ & & $\checkmark$ \\
\hline $\begin{array}{l}\text { Ophiactis savignyi (Müller \& Troschel, } \\
1842 \text { ) }\end{array}$ & & $\checkmark$ & $\checkmark$ \\
\hline \multicolumn{4}{|l|}{ Mollusca } \\
\hline Arca noae Linnaeus 1758 & & & $\checkmark$ \\
\hline Cypraea lurida (Linnaeus 1758) & & $\checkmark$ & $\checkmark$ \\
\hline Fissurella nubecula (Linnaeus 1758) & & & $\checkmark$ \\
\hline Mitra barbadensis (Gmelin, 1791) & & $\checkmark$ & \\
\hline Mitrella ocellata (Gmelin, 1791) & $\checkmark$ & & $\checkmark$ \\
\hline Nassarius $s p$ & $\checkmark$ & & \\
\hline Nerita ascensionis (Gmelin, 1791) & & $\checkmark$ & $\checkmark$ \\
\hline $\begin{array}{l}\text { Echinolittorina miliaris (Quoy \& } \\
\text { Gaimard, 1833) }\end{array}$ & $\checkmark$ & $\checkmark$ & $\checkmark$ \\
\hline Octopus vulgaris Cuvier 1797 & $\checkmark$ & & \\
\hline Saccostrea cucullata (Born 1778) & $\checkmark$ & $\checkmark$ & $\checkmark$ \\
\hline Stramonita rustica Lamarck 1822 & $\checkmark$ & $\checkmark$ & $\checkmark$ \\
\hline Platydoris cf. angustipes Morch 1863 & $\checkmark$ & & \\
\hline \multicolumn{4}{|l|}{ Cnidaria } \\
\hline Favia gravida Verrill 1868 & & $\checkmark$ & \\
\hline Millepora sp. & $\checkmark$ & & $\checkmark$ \\
\hline Medracis sp. & $\checkmark$ & $\checkmark$ & \\
\hline Siderastrea radians (Pallas, 1766) & $\checkmark$ & $\checkmark$ & $\checkmark$ \\
\hline \multicolumn{4}{|l|}{ Porifera } \\
\hline Haliclona sp. & $\checkmark$ & & $\checkmark$ \\
\hline Crambe sp. & $\checkmark$ & $\checkmark$ & $\checkmark$ \\
\hline Unknown demosponge 1 & $\checkmark$ & $\checkmark$ & \\
\hline Unknown demosponge 2 & & $\checkmark$ & $\checkmark$ \\
\hline Unknown demosponge 3 & & & $\checkmark$ \\
\hline Bryozoa & $\checkmark$ & & $\checkmark$ \\
\hline Terrestrial insects & $\checkmark$ & $\checkmark$ & $\checkmark$ \\
\hline
\end{tabular}

\section{Colonization of artificial substrata}

Taxa with planktonic wide-dispersing larvae, particularly small tubicolous polychaete worms (spirorbidae) and ascidians, were the earliest recruiting taxa and were the initial major space users on subtidal panels at Ascension I. This appears typical for recruitment onto shallow hard surfaces for localities reported worldwide (Goren, 1979; Lopez Gappa, 1989; Rauschert, 1991; Dalby \& Young, 1992; Relini et al., 1993; Maughan, 2000; Barnes \& Kuklinski, 2005). Despite, as reported elsewhere, considerable variability in colonization levels between panels, variability between sites within Ascension I. was not significant and in terms of space covered after a few months, colonization rates at Ascension I. were similar to those of the continental margin at both Tanzania and W Scotland as well as other values reported from low latitudes (Figure $4 \mathrm{~A}$ ). However, many low latitude studies have reported much higher coverage $(>50 \%)$ after just a few months' immersion (e.g. Jackson, 1977; Schoener \& Schoener, 1981; Barkai \& Branch, 1988; Maughan, 2000; Glassom et al., 2004). Ascension I. faunal cover was, after nearly 1 year of immersion (mean $16.2 \%$ ), considerably lower than reported from most temperate and tropical sites. In the north Atlantic Maughan (2000) reported that panels immersed for a year, across a variety of depths and flow rates, were nearly completely covered by fauna while Caribbean panels immersed for similar periods can be nearly 90\% covered (e.g. Winston \& Jackson, 1982; Carlon, 2001). However Arnold (2011) found cover as low as $24 \%$ and $28 \%$ after a year in Guatemala and Belize respectively (rising to $51 \%$ and $43-60 \%$ by year 2). Coverage of Ascension I. panels was more comparable with some remote or polar sites (Holmes et al., 1997; Bowden et al., 2006) but higher than that reported from remote (and) polar sites (Barnes, 1996; Barnes \& Kuklinski, 2005). Despite there clearly being many spatial, temporal and other (such as flow rate or predation) factors causing considerable intra-site variability, it seems that typically rate of space occupation can be ranked as temperate/tropical $>$ polar and remote temperate/ tropical $>$ remote polar. Geological age is likely to be superimposed over such ranking with older islands having much richer and diverse marine assemblages.

The number of taxa (genera) present on panels immersed at Ascension I. was similar to two sites at Hawaii after the same period (Schoener et al., 1978). Richness between panels varied by a factor of three, but was not linked to site. As with space occupation though, taxon accumulation overall was considerably lower than reported from most temperate and tropical studies of non-remote sites (e.g. Jackson, 1977; Goren, 1979; Schoener \& Schoener, 1981; Field, 1982; Pisano \& Boyer, 1985; Holmes et al., 1997). The hypothesis that richness levels would be low at isolated Ascension I. compared with reported rates of taxon accumulation onto similar panels at non-remote localities can be accepted. Also, as hypothesized, few (only three) cheilostomatid bryozoan morpho-types (identity not resolved in the current study) were found. Holmes et al. (1997) also found few bryozoans on their offshore sites, even though these were much closer to the continental shelf than Ascension I. The scarcity of different bryozoans on panels at Ascension I. contrasts strongly with reported richness in early assemblage development on panels elsewhere. The essentially benthic, lecithotrophic larvae typical of most cheilostomatid bryozoans, have much reduced dispersal opportunities compared with those of the main colonizing taxa (spirorbid and serpulid polychaetes, demosponges, ascidians and barnacles) at Ascension I. and elsewhere, which have mainly pelagic larvae (of various durations). Bryozoans seem to be poorly represented at young (Arntz et al., 2006) but not old isolated polar islands (Stanwell-Smith \& Barnes, 1997; Barnes \& Kuklinski, 2005), though no actual panel or other colonization studies have been reported from a young remote polar island to date. 

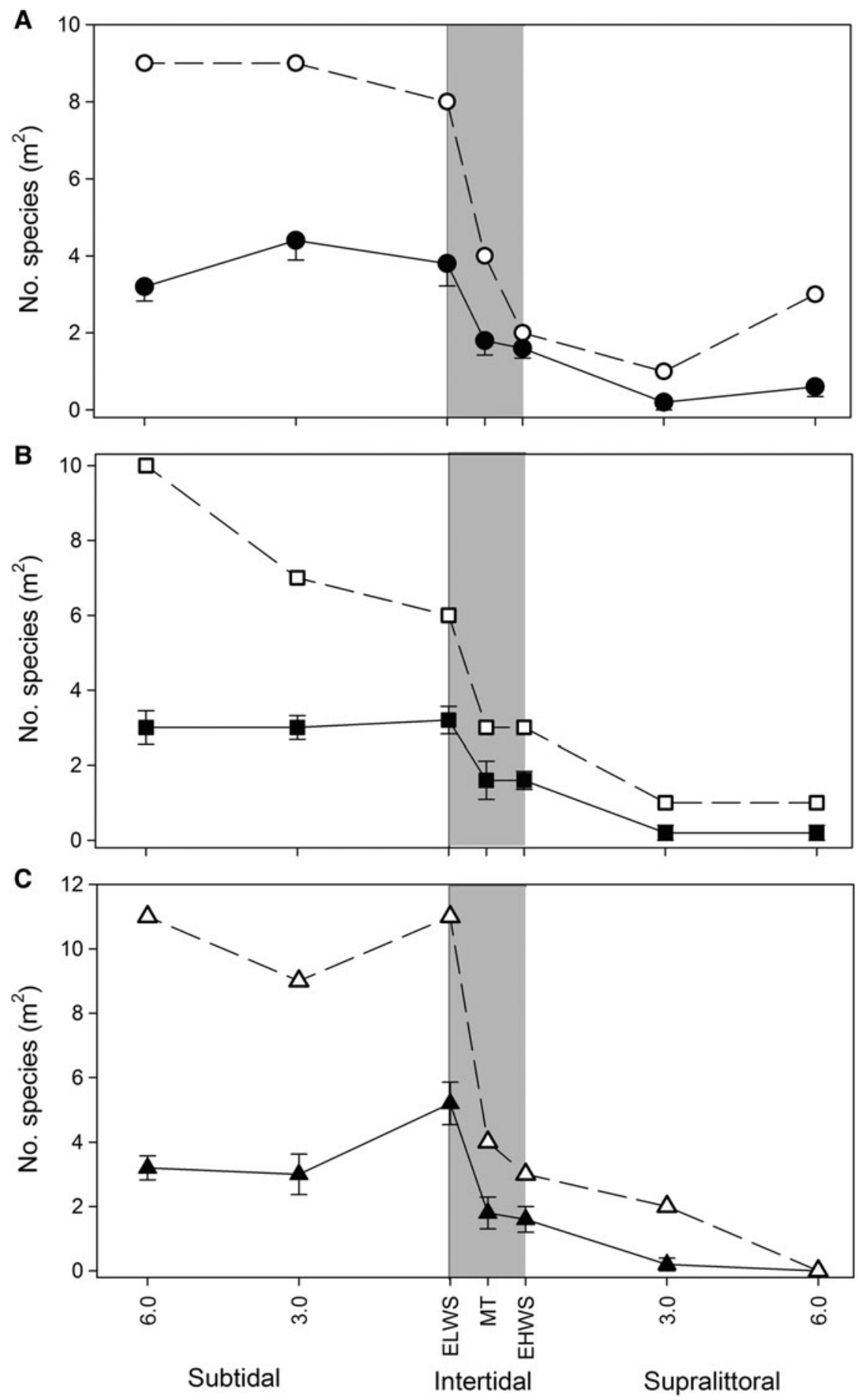

Height relative to littoral zone $(\mathrm{m})$

Fig. 5. Total (open symbols) and mean numbers (filled symbols) of established macro-epifaunal species across the land-sea interface zones at three sites at Ascension Island. The three sites are English Bay (a), North East Bay (b) and Shelley Bay (c). The littoral zone is shaded in grey and means are shown with standard error. ELWS, Extreme Low Water Spring tide level; EHWS, Extreme High Water Spring tide level; MT, Mid tide level.

Recruit abundance or density has been one of the most measured metrics of marine colonization to panels or natural substrata. At Ascension I. overall recruit densities were very low, lower than at other tropical, temperate or polar sites reported in the literature (Figure $4 \mathrm{~B})$ (e.g. Goren, 1979; Chalmer, 1982; Pisano \& Boyer, 1985; Todd, 1998; Maughan, 2000). Even some studies of single taxa, such as corals or barnacles, recruiting to panels have recorded higher densities (Fisk \& Harriott, 1990). Most studies on hardsubstratum recruitment of tropical and subtropical shores have focused on the hermatypic corals.

\section{Coral recruitment}

In the last two decades a large literature has developed on the spatial and temporal variability of coral recruitment rates. 

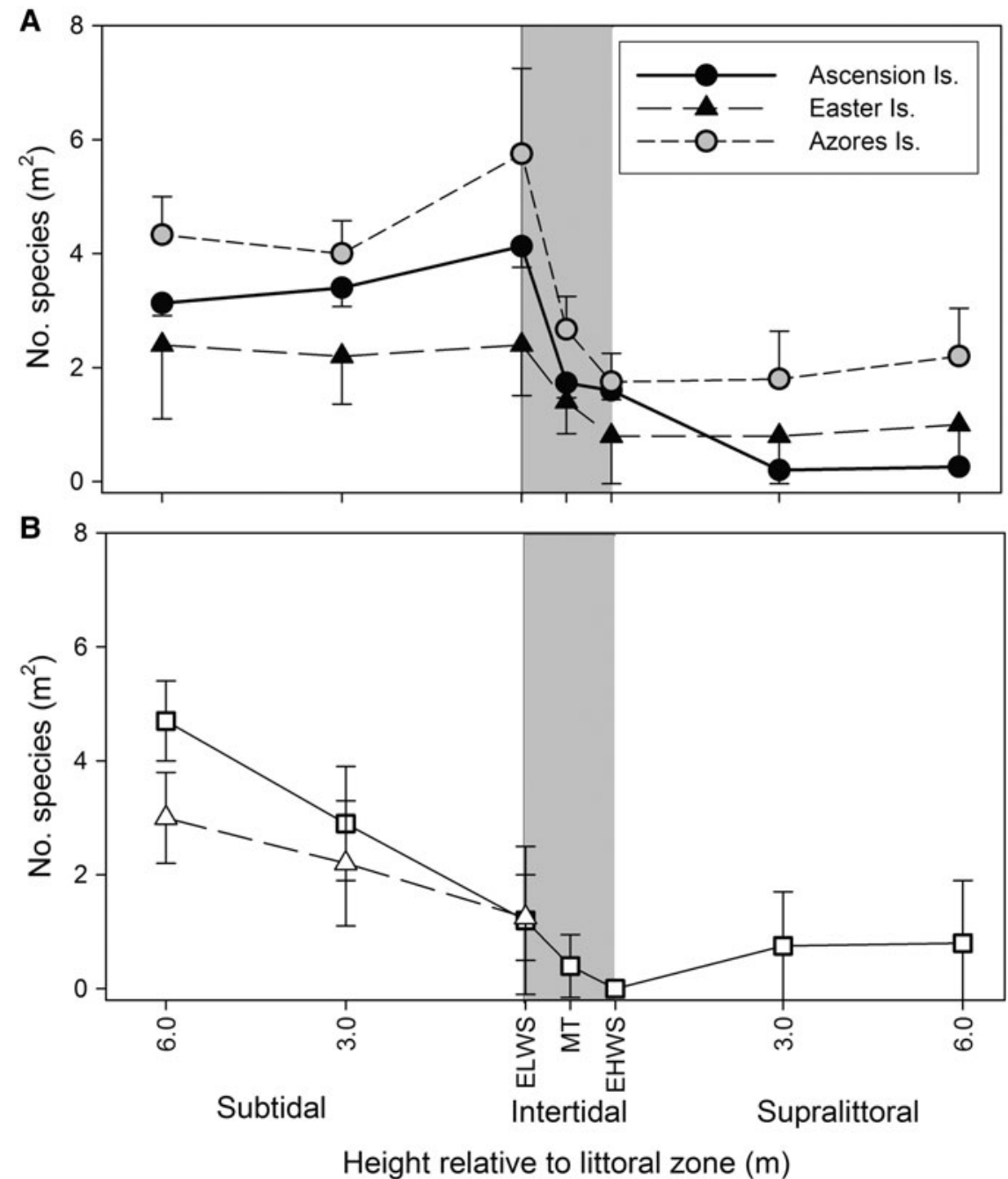

Fig. 6. Mean numbers of established macro-epifaunal species across the land-sea interface zones at three sites at three low (upper plot) and two high (lower plot) latitude mid-ocean islands.

This includes studies from continent margins to offshore islands and even a few mid ocean islands. The current study value of $25 \mathrm{~m}^{-2}$ at Ascension I. is comparable with the lowest levels found elsewhere at Atlantic locations (Table 4), except at Guatemala where Arnold (2011) recorded virtually no recruitment over two years. Ascension I. recruitment levels were similar to those reported from the other remote Atlantic island studied (Bermuda, see Smith 1985, 1992). Coral recruitment to panels and adjacent natural substrata at Ascension I. were comparable, but were low. Smith (1992) found lower levels of coral recruitment to panels in Bermuda, but this was confounded by panel and natural substratum data being collected in different years. Most of the highest coral recruitment levels (to natural reefs rather than settlement panels) in the Atlantic have been reported from Curacao, but these have declined from 15.3 per $\mathrm{m}^{2}$ in 1976 to 6.9 per $\mathrm{m}^{2}$ by 2005 (Vermeij et al. 2011). Values from Pacific localities vary more than those reported from the Atlantic but are typically higher (Table 4). Nevertheless the coral recruitment measured from 2003 to 2005 at Ascension I. was higher than measured during a similar time period at the remote Pacific (Hawaiian) islands of Midway $\left(7 \mathrm{~m}^{-2}\right)$ and Pearl and Hermes $\left(18 \mathrm{~m}^{-2}\right)$ (Friedlander et al., 2005). Friedlander et al. (2005) reported

Table 3. Previous recruitment studies using settlement panels in the subtidal zone at remote islands.

\begin{tabular}{llllllll}
\hline Location & Latitude & \% Cover & Classes/species & Duration & Depth $(\mathbf{m})$ & Panel size $(\mathbf{c m})$ & Authors \\
\hline Spitsbergen & $78^{\circ} \mathrm{N}$ & $3-11$ & $3 / 20$ & 1 years & 12 & $15 \times 15$ & Barnes \& Kuklinski $(2005)$ \\
Bermuda & $36^{\circ} \mathrm{N}$ & $\mathrm{ND}$ & Corals & $4-9$ months & $5-7$ & Smith $(1985)$ \\
NW Hawaii & $25^{\circ} \mathrm{N}$ & $\mathrm{ND}$ & Corals & $\sim 4$ years & 20 & $15 \times 15$ & Friedlander et al. $($ 2005) \\
Hawaii & $21^{\circ} \mathrm{N}$ & $\mathrm{ND}$ & $5 / 8$ & 1 years & 16 & $15 \times 31$ & Schoener et al. $(1978)$ \\
Lord Howe I. & $31^{\circ} \mathrm{S}$ & $1-4$ & $/ 20$ & 1.3 years* & $6-9$ & $15 \times 15$ & Holmes et al. $(1997)$ \\
Signy I., Ant & $60.5^{\circ} \mathrm{S}$ & $0.1-3$ & $3 / 22$ & $\sim 2$ years & $6,12,25$ & $15 \times 15$ & Barnes $(1996)$ \\
Signy, Ant & $60.5^{\circ} \mathrm{S}$ & $2-10$ & $4 / 23$ & $\sim 2$ years & $5,8,25$ & $15 \times 15$ & Stanwell-Smith \& Barnes $(1997)$ \\
\hline
\end{tabular}


Table 4. Coral recruitment onto settlement panels with location and experiment duration.

\begin{tabular}{|c|c|c|c|}
\hline Location & $\begin{array}{l}\text { Coral recruits } \\
\left(\mathbf{m}^{-2} \mathrm{yr}^{-1}\right)\end{array}$ & $\begin{array}{l}\text { Duration } \\
\text { months }\end{array}$ & Authors \\
\hline Ascension I. & 25 & 24 & This study \\
\hline Bermuda & $15-160$ & $2-9$ & Smith $(1985,1992)$ \\
\hline Florida & $130-270$ & ND & Smith (1997) \\
\hline St Croix & $80-90$ & 26 & Rogers et al. (1984) \\
\hline Jamaica & $8-370$ & 11 & Sammarco (1980) \\
\hline $\begin{array}{l}\text { British Virgin } \\
\text { Islands }\end{array}$ & $133-333$ & 24 & Carlon (2001) \\
\hline Mexico & 123 & 18 & $\begin{array}{l}\text { Baggett \& Bright } \\
\quad(1985)\end{array}$ \\
\hline Red Sea & 190 & $3-4$ & Glassom et al. (2004) \\
\hline Tanzania & $1-2133$ & 24 & $\begin{array}{l}\text { Nzali et al. (1998), } \\
\text { This study }\end{array}$ \\
\hline $\begin{array}{l}\text { Komodo, } \\
\text { Indonesia }\end{array}$ & $285-772$ & 36 & Fox $(2004)$ \\
\hline $\begin{array}{l}\text { Great Barrier } \\
\text { Reef }\end{array}$ & $22-879$ & 126 & $\begin{array}{l}\text { Wallace }(1985), \text { Fisk \& } \\
\text { Harriott (1990) }\end{array}$ \\
\hline Lord Howe I. & $0.1-1.1 \%$ & $4-8$ & Holmes et al. (1997) \\
\hline Guam & 160 & 6 & Birkeland et al. (1981) \\
\hline $\begin{array}{l}\text { Hawaiian } \\
\text { archipelago }\end{array}$ & $2-2307-270$ & 660 & $\begin{array}{l}\text { Fitzhardinge }(1985) \text {, } \\
\text { Friedlander et al. } \\
\quad(2005)\end{array}$ \\
\hline Tahiti & 131 & 4 & Gleason (1996) \\
\hline
\end{tabular}

coral recruitment levels at least an order of magnitude higher at other Hawaiian islands, levels which seemed to be little different from non-remote localities such as the Great Barrier Reef, Australia. The most recent review of coral recruitment at Ascension Island is that by Irving (2013). Current study values from Tanzania are little different to those reported from other protected areas in the region (Nzali et al., 1998), or indeed from levels at Ascension Island. The level of cover by corals was very low and may help to explain the low recruitment found on panels. Direct relationships between adult coral cover and larval recruitment are debated (Nzali et al., 1998; Hughes et al., 2000).

\section{Mortality and links between recruitment and establishment}

Price \& John $(1978,1980)$ suggested trigger fish (Melichthys niger) to be important agents of mortality to Ascension I. benthos. They also reported high echinoid densities, which can be prolific grazers of sessile recruits on hard surfaces (see Hutchings 1986 for sea urchin grazing pressure on reef invertebrates). Fish or echinoid exclusion devices were not considered in the current study, in part because the main focus was on the down-facing surface of the panels which only had a $2 \mathrm{~cm}$ gap to bedrock. No M. niger observed were small enough to access this and only very small echinoids could squeeze in. Observations made during the course of this study supported $M$. niger predation to be important, although crushing associated with boulder movement in wave action was also clearly common. One littoral boulder $\left(\sim 6 \mathrm{~m}^{3}\right)$ observed in 2002 had either completely disintegrated or been moved in 2003. Such crushing of shore communities may have parallels to ice scour, which destroys communities (and settlement panels) in polar regions (Barnes, 1996; Bowden et al., 2006). The taxa and patchiness on the panels were similar to the established sessile taxa of the surrounding communities recorded by the surveys after 2 years but benthos density differences on panels $\left(5400\right.$ ind $\left.\mathrm{m}^{-2}\right) v s$ the surrounding shore $\left(82.6\right.$ ind $\left.\mathrm{m}^{-2}\right)$ suggests a severe $(>99.8 \%)$ mortality level.

\section{CONCLUSIONS}

Ascension I. panels showing the highest levels of colonization showed seven times more space occupancy, double the recruit density and three times as many taxa than the panels showing the lowest recruitment success. Despite such a level of variability, which is not uncommon elsewhere, the overall level of colonization is clearly low. Even so the number of total recruits is low compared with elsewhere in the world, though coral recruitment was equivalent to the lower rates reported at other remote islands. Despite there being a substantial literature regarding the colonization of remote oceanic islands by terrestrial taxa and hermatypic corals, there is little information on other marine taxa. Even so it is clear that littoral/sublittoral colonization of remote islands is impoverished and particularly so at young sites. As hypothesized colonization taxa with non-dispersive larvae were poorly represented at Ascension I. Adult community richness is essentially similar across the littoral zone on remote islands with the zone immediately above the shore being least colonized.

\section{ACKNDWLEDGEMENTS}

I would like to thank Professor Lloyd Peck, Dr Katrin Linse, Dr Keiron Fraser, Dr Daniel Smale, Dr Philip Pugh, Jenny Beaumont and the volunteers of FRONTIER TANZANIA for support of various pieces of this work. I would also like to thank Jonny Stark for use of unpublished data and Elanor Gowland for production of Figure 1. This manuscript is a contribution to the BEAT team at the British Antarctic Survey (NERC).

\section{REFERENCES}

Arnold S.N. (2011) Spatial and temporal scales of coral recruitment and key ecological processes. Unpublished $\mathrm{PhD}$ thesis. University of Maine Orono, ME

Arntz W., Thatje S., Linse K., Avila C., Ballesteros M., Barnes D.K.A., Cope T., Cristobo Rodríguez F.J., De Broyer C., Gutt J., Isla E., López-González P., Montiel A., Munilla T., Ramos Esplá A., Raupach M., Rauschert M., Rodriguez E. and Teixidó N. (2006) Missing link in the Southern Ocean: sampling the marine benthic fauna of remote Bouvet Island. Polar Biology 29, 83-96.

Baggett L.S. and Bright T.J. (1985) Coral recruitment at the East Flower Garden Reef (Northwestern Gulf of Mexico). Proceedings of the 5th International Coral Reef Congress 4, 379-384.

Ballantine W.J. (1961) A biologically-defined exposure scale for the comparative description of rocky shores. Field Studies 1, 73-84.

Barkai A. and Branch G.M. (1988) The influence of predation and substratal complexity on recruitment to settlement plates: a test of the theory of alternative states. Journal of Experimental Marine Biology and Ecology 124, 215-237. 
Barnes D.K.A. (1996) Low levels of colonisation in Antarctica: the role of bryozoans in early community development. In Gordon D.P., Smith A.M. and Grant-Mackie J.A. (eds) Bryozoans in space and time. Proceedings of the 1oth International Bryozoology Conference. Wellington, NZ: National Institute of Water and Atmospheric Research, pp. 19-28.

Barnes D.K.A. and Kuklinski P. (2005) Low colonisation on artificial substrata in arctic Spitsbergen. Polar Biology 29, 65-69.

Beckley L.E. and Branch G.M. (1992) A quantitative scuba-diving survey of the sublittoral macrobenthos at subantarctic Marion Island. Polar Biology 11, 553-563.

Biernbaum C.K. (1996) Biogeography of coastal and anchialine amphipods of Ascension Island, South Atlantic Ocean. Journal of Natural History 30, 1597-1615.

Birkeland C., Rowley D. and Randall R.H. (1981) Coral recruitment patterns at Guam. Proceedings of the 4th International Coral Reef Symposium 2, 339-344.

Bouchet P., Lozouet P., Maestrati P. and Heros V. (2002) Assessing the magnitude of species richness in tropical marine environments: exceptionally high numbers of molluscs at a New Caledonia site. Biological Journal of the Linnean Society 75, 421-436.

Bourmaud C.A.F., Abouïdane A., Boissier P., Leclère L., Mirault E. and Pennober G. (2005) Coastal and marine biodiversity of La Réunion. Indian Journal of Marine Science 34, 98-103.

Bowden D., Clarke A., Peck L.S. and Barnes D.K.A. (2006) Antarctic sessile marine benthos: colonisation and growth on artificial substrata over three years. Marine Ecology Progress Series 316, 1- 16.

Carlon D.B. (2001) Depth-related patterns of coral recruitment and cryptic suspension-feeding invertebrates on Guana Island, British Virgin Islands. Bulletin of Marine Science 68, 525-541.

Chalmer P.N. (1982) Settlement patterns of species in a marine fouling community and some methods of succession. Journal of Experimental Marine Biology and Ecology 58, 73-85.

Cole R.G., Creese R.G., Grace R.V., Irving P. and Jackson B.R. (1992) Abundance patterns of subtidal benthic invertebrates and fishes at the Kermadec Islands. Marine Ecology Progress Series 82, 207-218.

Dalby J.E. and Young C.M. (1992) Role of early post-settlement mortality in setting the upper depth limit of ascidians in Florida fouling communities. Marine Ecology Progress Series 80, 221-228.

Davenport J. and Stevenson T.D.I. (1998) Intertidal colonization rates. A matched latitude, north v. south, remote v. near shore island experiment. Diversity and Distributions 4, 87-92.

Field B. (1982) Structural analysis of fouling community development in the Damariscotta River estuary, Maine. Journal of Experimental Marine Biology and Ecology 57, 25-33.

Fisk D.A. and Harriott V.J. (1990) Spatial and temporal variation in coral recruitment on the Great Barrier Reef: implications for dispersal hypotheses. Marine Biology 107, 485-490.

Fitzhardinge R. (1985) Spatial and temporal variability in coral recruitment in Kaneohe Bay (Oahu, Hawaii). Proceedings of the 5th International Coral Reef Symposium 4, 373-378.

Fox H.E. (2004) Coral recruitment in blasted and unblasted sites in Indonesia: assessing rehabilitation potential. Marine Ecology Progress Series 269, 131-139.

Friedlander A.M., Aeby G., Brown E., Clark A., Coles S., Dollar S., Hunter C., Jokiel P., Smith J., Walsh B., Williams I. and Wiltse W. (2005) The state of coral reef ecosystems of the main Hawaiian Islands. In Waddel J. (ed.) The state of coral reef ecosystems of the United States and Pacific Freely Associated States: 2005. NOAA Technical Memorandum NOS NCCOS 11. NOAA/NCCOS Center for
Coastal Monitoring and Assessment's Biogeography Team. Silver Springs, MD: NOAA, pp. 222-269.

Glassom D., Chadwick-Furman N.E. and Zakai D. (2004) Coral recruitment: a spatio-temporal analysis along the coastline at Eilat, northern Red Sea. Marine Biology 144, 641-651.

Gleason M.G. (1996) Coral recruitment in Moorea, French Polynesia: the importance of patch type and temporal variation. Journal of Experimental Marine Biology and Ecology 207, 79-101.

Goren B.H. (1979) Succession of a benthic community on an artificial substratum at Eilat, Red Sea. Journal of Experimental Marine Biology and Ecology 38, 19-40.

Holmes N.J., Harriott V.J. and Banks S.A. (1997) Latitudinal variation in patterns of colonisation of cryptic calcareous marine organisms. Marine Ecology Progress Series 155, 103-113.

Hoeksema B., Nunes F.L.D., Lindner A. and Nunes de Sousa J. (2017) Millepora alcicornis (Hydrozoa: Capitata) at Ascension Island: confirmed identity based on morphological and molecular analyses. Journal of the Marine Biological Association of the United Kingdom 97, 709-712.

Hughes T.P., Baird A.H., Dinsdale E.A., Moltschaniwskyj N.A., Pratchett M.S., Tanner J.E. and Willis B.L. (2000) Supply-side ecology works both ways: the link between benthic adults, fecundity, and larval recruits. Ecology 81, 2241-2249.

Hutchings P.A. (1986) Biological destruction of coral reefs. Coral Reefs 4, 239-252.

Irving R. (2013) Ascension Island's hermatypic but non-reef building corals. In Sheppard C. (ed.) Coral reefs of the United Kingdom Overseas Territories. Dordrecht: Springer, pp. 213-221.

Irving R.A. (1989) A preliminary investigation of the sublittoral habitats and communities of Ascension Island, South Atlantic. Progress in Underwater Science 13, 65-78.

Jackson J.B.C. (1977) Competition on marine hard substrata: the adaptive significance of solitary and colonial strategies. American Naturalist $111,743-767$.

Lopez Gappa J. (1989) Overgrowth competition in an assemblage of encrusting bryozoans settled on artificial substrata. Marine Ecology Progress Series 51, 121-130.

Lubbock R. (1980) The shore fishes of Ascension Island. Journal of Fish Biology 17, 283-303.

Maddocks R.F. (1975) Recent Bairiidae (Ostracoda) from Ascension island. Crustaceana 28, 53-65.

Manning R. and Chace F.A. (1990) Decapod and stomatopod crustacea from Ascension Island, South Atlantic Ocean. Smithsonian Contributions to Zoology 503, 1-91.

Markham J.C. (1978) Bopyrid isopods parasitizing hermit crabs in the northwestern Atlantic Ocean. Bulletin of Marine Sciences 28, $102-117$.

Maughan B. (2000) Ecology of encrusting epifaunal in Lough Hyne Marine Nature Reserve, Co. Cork, Ireland. Unpublished PhD thesis. University College Cork, Ireland.

Mitchell-Thome R.C. (1982) The geological settings and characteristics of the Atlantic islands. Acta Geologica Academy of Science Hung 25, $395-420$.

Moyano G.H.I. (1973) Briozoos marinos Chilenos I. Briozoos de la Islas de Pascua I. Gayana Zoologia, Concepcion 25, 1-22.

Nzali L.M., Johnstone R.W. and Mgaya Y.D. (1998) Factors affecting scleractinian coral recruitment on a nearshore reef in Tanzania. Ambio 27, 717-722.

Pawson D. (1978) The Echinoderm fauna of Ascension Island, South Atlantic Ocean. Smithsonian Contributions to Science 2, 1-31. 
Pisano E. and Boyer M. (1985) Development pattern of an infralittoral bryozoan community in the western Mediterranean Sea. Marine Ecology Progress Series 27, 195-202.

Price J.H. and John D.M. (1978) Subtidal ecology in Antigua and Ascension: a comparison. Progress in Underwater Science (Report of the Underwater Association) 3, 111-133.

Price J.H. and John D.M. (1980) Ascension island, South Atlantic: a survey of inshore benthic macroorganisms, communities and interactions. Aquatic Botany 9, 251-278.

Pugh P.J.A. and Mercer R.D. (2001) Littoral Acari of Marion island: ecology and extreme wave action. Polar Biology 24, 239-243.

Rauschert M. (1991) Ergebnisse der faunistischen arbeiten im benthal von King George Island (Sudshetlandinseln, Antarktis). Berichte Polarforschung Meeresforsch 76, 1-75.

Relini G., Amato E. and Relini M. (1993) Macrofouling in Antarctic waters. Oebalia 19, 625-628.

Rogers C.S., Fitz H.C., Gilnack M., Beets J. and Hardin J. (1984) Scleractinian coral recruitment patterns at Salt River Submarine Canyon, St. Croix, US Virgin Islands. Coral Reefs 3, 69-76.

Rosewater J. (1975) An annotated list of the marine molluscs of Ascension Island, south Atlantic Ocean. Smithsonian Contributions to Zoology 189, 1-41.

Sammarco P.W. (1980) Diadema and its relationship to coral spat mortality: grazing competition and biological disturbance. Journal of Experimental Marine Biology and Ecology 45, 245-272.

Schoener A., Long E.R. and DePalma J.R. (1978) Geographic variation in artificial island colonization curves. Ecology 59, 367-382.

Schoener A. and Schoener T.W. (1981) The dynamics of the species-area relation in marine fouling systems. 1. Biological correlates of changes in the species-area slope. American Naturalist 118, 339-360.

Smith S.R. (1985) Reef damage and recovery after ship groundings on Bermuda. Proceedings of the 5 th International Coral Reef Symposium $6,497-502$

Smith S.R. (1992) Patterns of coral recruitment and post-settlement mortality on Bermuda's reefs: comparisons to Caribbean and Pacific reefs. American Journal of Zoology 32, 663-673.

Smith S.R. (1997) Patterns of coral settlement, recruitment and juvenile mortality with depth at Conch Reef, Florida. Proceedings of the 8th International Coral Reef Symposium 2, 1197-1202.

Stanwell-Smith D. and Barnes D.K.A. (1997) Benthic community development in Antarctica: recruitment and growth on settlement panels at Signy Island. Journal of Experimental Marine Biology and Ecology 212, $61-79$.
Todd C.D. (1998) Larval supply and recruitment of benthic invertebrates: do larvae always disperse as much as we believe? Hydrobiologia 376 , $1-21$.

Todd C.D. and Keough M.J. (1994) Larval settlement in hard substratum epifaunal assemblages - a manipulative field study of the effects of substratum filming and the presence of incumbents. Journal of Experimental Marine Biology and Ecology 181, 159-187.

Turner S.J. and Todd C.D. (1993) The early development of epifaunal assemblages on artificial substrata on two intertidal sites on an exposed rocky shore in St Andrews bay, NE Scotland. Journal of Experimental Marine Biology and Ecology 166, 251-272.

Vermeij M.J.A., Bakker J., van der Hal N. and Bak R.P.M. (2011) Juvenile coral abundance has decreased by more than $50 \%$ in only three decades on a small Caribbean island. Diversity 3, 296-307.

Wallace C.C. (1985) Seasonal peaks and annual fluctuations in recruitment of juvenile scleractinian corals. Marine Ecology Progress Series 21, 289-298.

Watson D. and Barnes D.K.A. (2004) Temporal and spatial components of variability in benthic recruitment, a 5 year temperate example. Marine Biology 145, 201-214.

Węsławski J.M., Zajączkowski M., Kwaśniewski S., Jezierski J. and Moskal W. (1988) Seasonality in an Arctic fjord ecosystem: Horsunfjord, Spitsbergen. Polar Research 6, 185-189.

Winston J.E. and Jackson J.B.C. (1982) Ecology of cryptic coral reef communities 1. Distribution and abundance of major groups of encrusting organisms. Journal of Experimental Marine Biology and Ecology 57, $135-147$.

Winston J.E. and Jackson J.B.C. (1984) Ecology of cryptic coral reef communities 4. Community development and life histories of encrusting cheilostome Bryozoa. Journal of Experimental Marine Biology and Ecology 76, 1-21.

and

Zibrowius H., Wirtz P., Nunes F.L.D., Hoeksema B.W. and Benzoni F. (2017) Shallow-water scleractinian corals of Ascension Island, Central South Atlantic. Journal of the Marine Biological Association of the United Kingdom 97, 713-725.

\section{Correspondence should be addressed to:}

D.K.A. Barnes

British Antarctic Survey, Natural Environment Research Council, High Cross, Madingley Road, Cambridge $\mathrm{CB}_{3}$ OET, UK.

email: dkab@bas.ac.uk 